\title{
Ecological Service Evaluation: An Empirical Study on the Central Loess Plateau, China
}

\author{
Yang Li ${ }^{1}$, Pengjun Zhang ${ }^{2}$, Yaochen Qin ${ }^{1 *}$ \\ ${ }^{1}$ College of Environment and Planning, Henan University, Kaifeng, China \\ Key Laboratory of Geospatial Technology for Middle and Lower Yellow River Regions \\ Henan Collaborative Innovation Center of Urban-Rural Coordinated Development, Zhengzhou, China \\ ${ }^{2}$ School of Education, Henan University, Kaifeng, China
}

Received: 30 April 2019

Accepted: 10 July2019

\begin{abstract}
This research using the Net Primary Production (NPP), grain yield, and rainfall to dynamically revised the unit area Ecosystem Service Value (ESV) equivalent factor in the Loess Plateau. A dynamic evaluation model of the Loess Plateau ecosystem service value was established to evaluate the ESV as well as spatial and temporal dynamic evolution characteristics. From 1990 to 2015, the dynamic degree of ecological land in the study area was $8.867 \%$. Apart from paddy fields, dry land, and deserts, the transfer rates showed an increasing trend. Bare land was converted into other land use types at an increasing rate, while forest areas increased slowly and cultivated areas first increased and then decreased. Grassland areas only slightly decreased, while wetland and water areas remained relatively stable. From 1990 to 2015, the ESV fluctuated largely, albeit with an overall improvement. The ecosystem service value showed an obvious spatial heterogeneity, with higher values in the south compared to the north of the Loess Plateau.
\end{abstract}

Keywords: ESV, calibration factor, transition matrix, spatial-temporal pattern, Loess Plateau

\section{Introduction}

In 1935, the British ecologist Tansley proposed that an ecosystem is an ecological functional unit formed by the exchange of material and energy between biological and non-biological components within a certain spatial range [1]. Ecosystem service value (ESV) refers to the sum of benefits from supply, regulation, support and cultural services from the ecosystem in a direct or indirect way [2]. In this sense, ecosystem service

*e-mail: qinyc@henu.edu.cn value evaluation can imply energy value analysis, value quantity evaluation, and alternative cost method, and represents an important basis for eco-environmental economic accounting, eco-functional zoning, and environmental protection; for this reason, it has become a research hotspot in several industries [3-4].

The Loess Plateau in China is characterized by a fragile ecological environment, complex natural and geographical conditions, frequent natural disasters, and unreasonable exploitation and use of ecological resources, which have led to significant damage to the regional ecological environment. Since the beginning of the $21^{\text {st }}$ century, the state has been managing and improving the ecological environment through 
a series of ecological rehabilitation projects, such as returning cultivated land to forest and grassland and the comprehensive rehabilitation of small river basins. Studies have shown that ecological restoration, even after decades of inadequate management, has an important impact on the ecological environment of the Loess Plateau [5-8], and the quality of the ecological environment is closely related to the value of its ecosystem services. Against this background, it is particularly important to reveal the spatial and temporal evolution of ecosystem service values and the process of environmental changes on the Loess Plateau region of northern Shaanxi. This study, through the analysis of ecosystem service values of space-time evolution characteristics, the investigation of regional harmonious development programs, the analysis of ecosystem service management policies [9], and the investigation of the relationship between regional social development and the ecological environment [10-13], aims to provide a theoretical basis for regional ecological environment construction, based on the prevention and control of soil erosion and on vegetation restoration.

In 1997, Costanza et al. [14] proposed the "equivalence factor method" and applied it to the evaluation of global ecosystem service values. Research on ecosystem service values has received widespread attention from a variety of fields and has become a leading topic in ecological economy, providing a scientific basis for regional and global sustainable development. Over the past decades, scholars have extensively studied and evaluated ecosystem service values, both on theoretical and empirical levels [15]. The theoretical level mainly focuses on the method revision and the improvement of ecosystem service value evaluation. In this regard, Xie et al. [16] have improved the assessment method of global ecosystem service values, constructed an ecosystem service value assessment method applicable to China based on expert knowledge, and completed the ESV assessment of Chinese terrestrial ecosystems. As the research scale of this evaluation method is the entire scope of China, the spatiotemporal heterogeneity of ecological service values requires the parameter revision of the evaluation method. Various scholars have therefore proposed the niche correction method [17] and the spatiotemporal heterogeneity revision method, based on biomass and crop yield unit area of farmland [18]. On the empirical level, ecosystem service values of land use categories are mainly simulated [19], and ecosystem service value assessment and spatiotemporal evolution [20-22] as well as response mechanisms of ecosystem service values and land use change [23-24] are the main aspects. Liu et al. [25] have adopted net primary productivity (NPP) as the functional correction coefficient of the equivalent factor in the study area. It can easily be seen that the improvement of the quantification method of ecological service value increases the accuracy of ecosystem service assessment to some extent. However, only a few studies have comprehensively considered the temporal and spatial heterogeneity of ESV and regional climatic conditions, and improvements in the evaluation method and accuracy are necessary.

In this context, this paper is based on the unit area ecosystem service value equivalent factor for China's terrestrial ecosystems and considers the spatial heterogeneity of ESV and time evolution. The innovation of this study lies in that it takes the spatio-temporal heterogeneity of the unit area ecosystem service value equivalent factor into account and carries out dynamic evaluation of ESV in the central loess plateau by establishing dynamic revision coefficient. The setting process of dynamic revision parameters is as follows: Functional regulation was carried out based on NPP and precipitation, while regional regulation was based on social and economic development data (cultivated area, yield and output values of the main grain crops, on income unit area, and crop yield unit area of the main grain crops in China). On this basis, the evaluation of ecosystem service values and spatiotemporal dynamic evolution characteristics analysis were carried out, using data from 1990 to 2015.

\section{Material and Methods}

\section{Study Area and Data Sources}

The Loess Plateau of Shaanxi Province $\left(34^{\circ} 10^{\prime} \mathrm{N}-35^{\circ} 39^{\prime} \mathrm{N}, 107^{\circ} 30^{\circ}-111^{\circ} 15^{\prime}\right.$ E) includes Yulin, Yan'an and Tongchuan City, Yijun County, Yao County, Xunyi County, Changwu County, Yongshou County, Bin County, and Chunhua County in Xianyang City [26]. The study area comprised Yan'an City and Yulin City (Fig. 1), covering a total area of 79,981.9 $\mathrm{km}^{2}$ and accounting for $12.6 \%$ of the total Loess Plateau. The landform is complex and diverse, with numerous steep slopes, gullies, and valleys; land use types comprise agriculture, forest, and pasture. Precipitation is not evenly distributed in space and time, with an average annual precipitation of $400-600 \mathrm{~mm}$, decreasing from southeast to northwest.

The data and data sources used in this study are as follows: land use data of the six periods from 1990 to 2015 were obtained from the resource and environmental science data center of the Chinese Academy of Sciences (http://www.resdc.cn), NPP data were obtained from the National Earth System Scientific Data Sharing Service Platform (http://www.geodata.cn), and precipitation data were derived from the China Meteorological Science Data Sharing Service Network (http://www.cma.Gov.Cn/ 2011QXFW/QSJGX/2011). Information on the cultivated area, yield and output values of the main grain crops, and on income unit area and crop yield unit area of the main grain crops in China were obtained from the statistical yearbook of China and Shaanxi Province. 


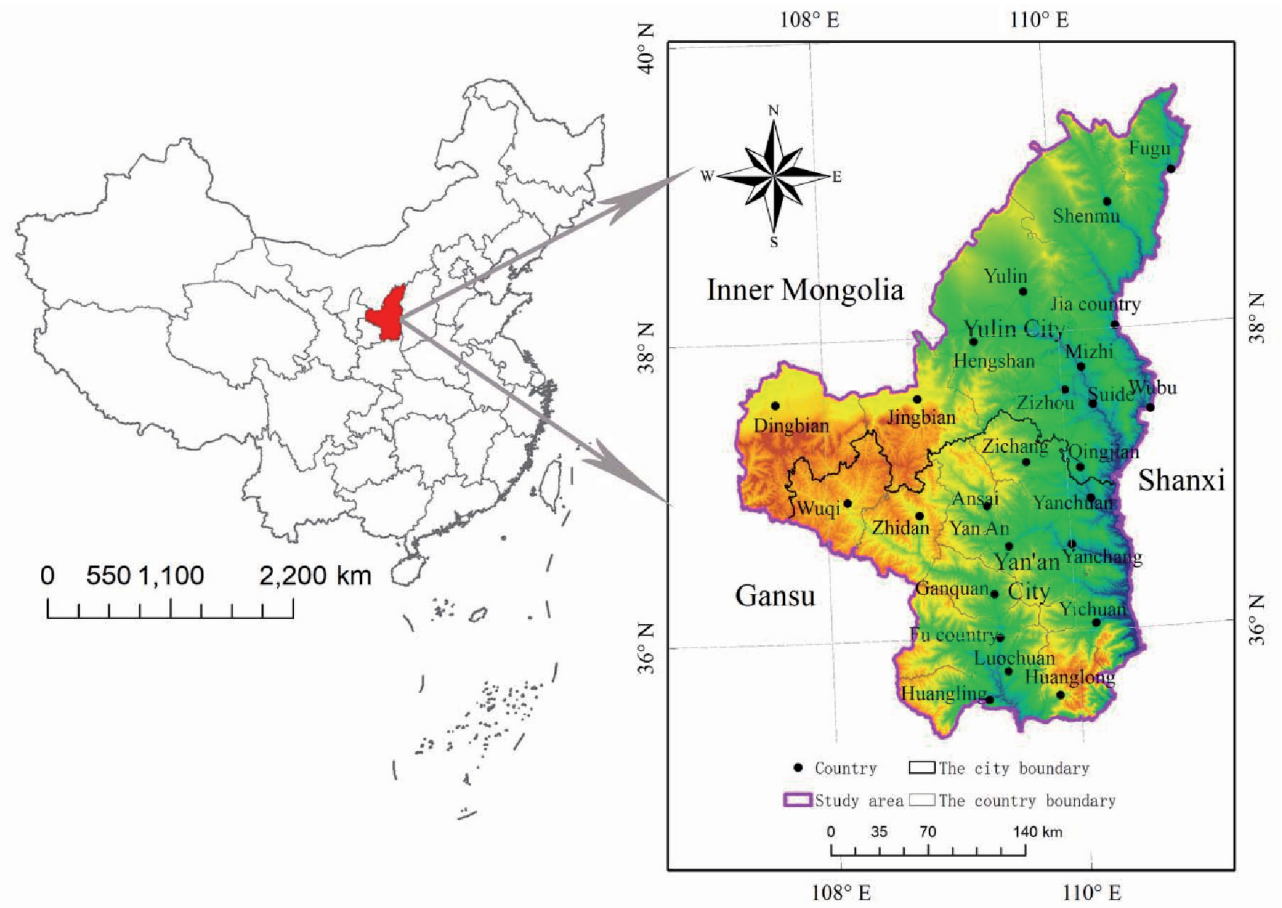

Fig. 1. Geographical location of the study area.

\section{Transfer Rate and Dynamic Degree}

The transfer rate of land use categories represents the transfer amount of land use categories within a certain period [27] and can be calculated as follows:

$$
\mathrm{P}_{i}=\frac{S_{i b}-S_{i a}}{s_{i a}} \times \frac{1}{n} \times 100 \%
$$

..where $\mathrm{P}_{\mathrm{i}}$ is the transfer rate of land use category $i ; \mathrm{S}_{\mathrm{ib}}$ is the area of the land use category $i\left(\mathrm{hm}^{2}\right)$ at the end of the period; $\mathrm{S}_{\mathrm{ia}}$ is the initial area $\left(\mathrm{hm}^{2}\right)$ of the land use category $i$; and $\mathrm{n}$ is the research period.

The dynamic degree of land use categories is the overall active degree of land use change [28], expressed as follows:

$$
\mathrm{Q}=\left\{\sum_{i j}^{n}\left(\Delta S_{i-j} / S_{i}\right)\right\} \times \frac{1}{t} \times 100 \%
$$

...where $\mathrm{Q}$ is the dynamic degree of land use; $\mathrm{S}_{i}$ is the area $\left(\mathrm{hm}^{2}\right)$ of the land use category $i$ in the initial period; $\Delta S_{i-j}$ is the area $\left(\mathrm{hm}^{2}\right)$ converted from land use category $i$ to another category; $t$ is the period of study; and $n$ is the number of land use categories.

\section{Construction of the Unit Area Ecological Service Value Dynamic Equivalent Factor}

The unit area ecological service value dynamic equivalent factor is the average annual value of the service functions of different land use categories within the unit area, which is the basis and premise for evaluating the various ecosystem service values.
According to Costanza et al. [14], the unit area ecosystem service values of different land use categories reflects the developed countries and regions in Europe and America. However, its application in China has regional variations. In this context, Xie et al. [29] carried out a questionnaire survey on 700 professionals with a background in ecology; based on these data, they modified the "equivalent factor method" adapted to the evaluation of ecosystem services in China, based on the status of China's ecosystem and social and economic development (Table 1). The time series dynamics and spatial heterogeneity of ecosystem service values require that the equivalent factors of these values in China are corrected when calculating them for the Loess Plateau. This study referred to related literature [16] and used the ratio of unit area crop yield between the study area and China in 2010 as the regional regulatory coefficient. The dynamic equivalent factor of ecosystem service values of the Loess Plateau of northern Shaanxi Province was constructed by combining the time and space regulatory coefficients of NPP and rainfall.

\section{Dynamic Equivalent Factor of Ecological Service Value of the Unit Area}

There are significant differences in biomass and climatic conditions between different research scales, regions, and time periods [30-31]. This study therefore determined the time-space dynamic regulation factors of biomass and precipitation, combined with the equivalent weight factor of ecosystem service value per hectare of terrestrial ecosystems in China, and constructed the dynamic equivalent of ecological service value of 
Table 1. Equivalent value per unit area of ecosystem service in China (unit: $\$ / \mathrm{hm}^{2}$ a).

\begin{tabular}{|c|c|c|c|c|c|c|}
\hline Type & Forest & Grassland & Cropland & Wetland & Water & Desert \\
\hline Food production & 0.05 & 0.06 & 0.15 & 0.05 & 0.08 & 0.00 \\
\hline Raw material & 0.44 & 0.05 & 0.06 & 0.04 & 0.05 & 0.01 \\
\hline Gas regulation & 0.64 & 0.22 & 0.11 & 0.36 & 0.08 & 0.01 \\
\hline Climate regulation & 0.61 & 0.23 & 0.14 & 2.02 & 0.31 & 0.02 \\
\hline Water purification and provision & 0.61 & 0.23 & 0.11 & 2.00 & 2.80 & 0.01 \\
\hline Waste purification & 0.26 & 0.20 & 0.21 & 2.15 & 2.21 & 0.04 \\
\hline Soil protection & 0.60 & 0.33 & 0.22 & 0.30 & 0.06 & 0.03 \\
\hline Biodiversity protection & 0.67 & 0.28 & 0.15 & 0.55 & 0.51 & 0.06 \\
\hline Recreation and culture & 0.31 & 0.13 & 0.03 & 0.70 & 0.66 & 0.04 \\
\hline Total & 4.19 & 1.74 & 1.18 & 8.17 & 6.76 & 0.21 \\
\hline
\end{tabular}

Note: Table 1 is referenced from Xie et al. [29]

the unit area on the Loess Plateau region of northern Shaanxi Province from 1990 to 2015, using the following equation:

$$
F_{n i j}=\left\{\begin{array}{l}
P_{i j} \times F_{n 1} \\
R_{i j} \times F_{n 2}
\end{array}\right.
$$

...where $F_{n i j}$ is the unit area service value equivalent factor of the ecosystem service function of category $n$ in period $j$ in region $i ; F_{n}$ is the ecological service value equivalent factor of category $n ; P_{i j}$ is the regulator factor of NPP in period $j$ in region $i ; R_{i j}$ is the regulator factor of precipitation in period $j$ in region $i$; $n 1$ is the service function of food production, gas regulation, climate regulation, and maintenance of biodiversity, etc.; and $n 2$ is the hydrological regulation service function.

(1) Spatio-temporal regulator factor of NPP

The ratio between the NPP value of the pixel and the mean national NPP value is used as the NPP adjustment coefficient, using the following equation:

$$
P_{i}=\frac{B_{i}}{\bar{B}}
$$

...where $P_{i j}$ is the annual NPP adjustment factor of grid cell $j$ in year $\mathrm{i}, B_{i j}$ is the NPP value of grid cell $j$ in year $\mathrm{i}$, and $\bar{B}$ is the nationwide average NPP of the ecotype. Table 2 shows the NPP variance from 1990 to 2015. It can be clearly seen from the NPP transfer matrix that the transition from low to high level of NPP was obvious from 1990 to 2015.

(2) Spatio-temporal regulating factors of precipitation

The national annual precipitation data were interpolated in Anusplin 43, and the corresponding annual average precipitation of each region was obtained; the precipitation regulation factors were calculated as follows:

$$
\mathrm{R}_{i j}=\frac{W_{i}}{\bar{W}}
$$

...where $W_{i}$ is the annual precipitation of a single pixel $\left(\mathrm{mm} / \mathrm{hm}^{2}\right)$ in the area studied in the year $i$ and $\bar{W}$ is the annual average rainfall $\left(\mathrm{mm} / \mathrm{hm}^{2}\right)$ in China. Table 3 shows that precipitation has an obvious enhancement from 1990 to 2015. It is not difficult to find from Table 3 that the precipitation of the study area in 2015 showed an increasing trend compared with that in 1990. The increase of precipitation is a beneficial change

Table 2. Transition matrix of NPP level from 1990 to 2015 (unit: $\mathrm{km}^{2}$ ).

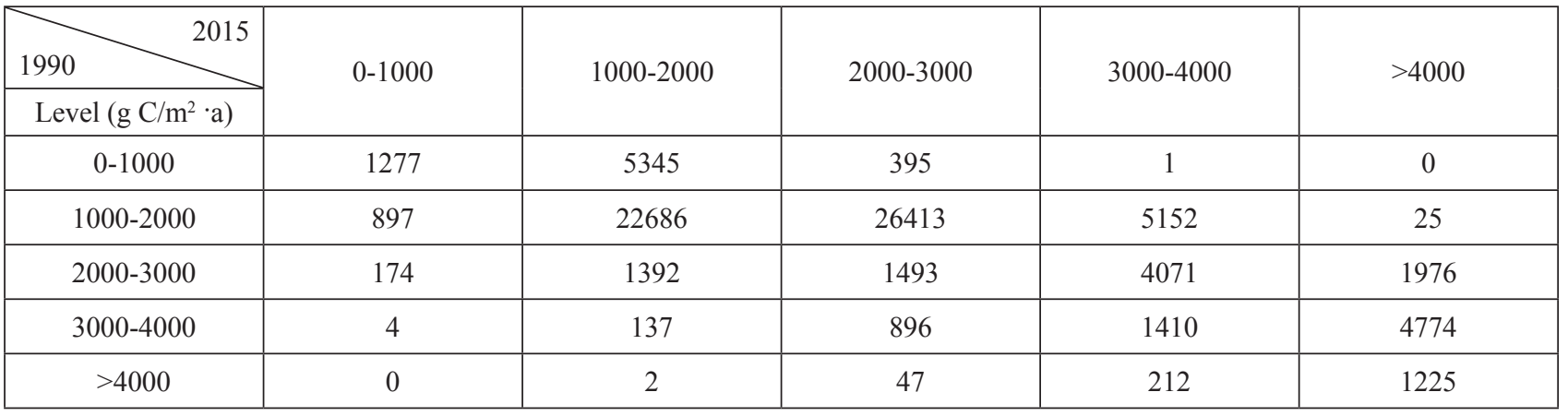


Table 3. Transition matrix of precipitation level from 1990 to 2015 (unit: $\mathrm{km}^{2}$ ).

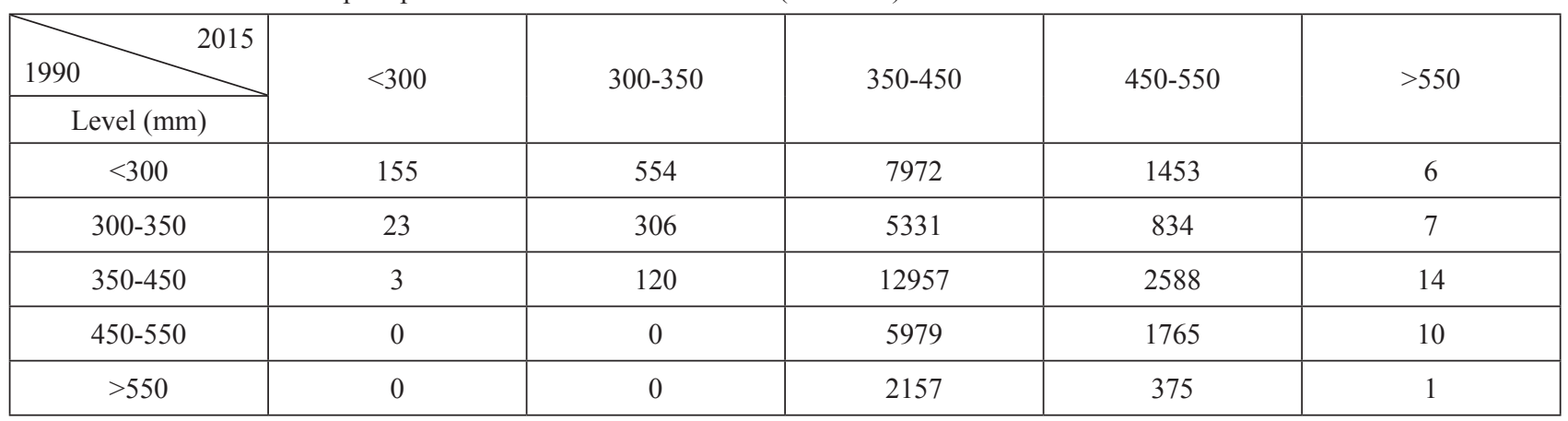

for the Loess Plateau, which has been short of water resources for a long time.

\section{Calculation of ESV}

The calculation of the ecosystem service value of one standard equivalent factor is referred to $\mathrm{Xie}$ et al. [29], who claimed that the natural food production generated by the cropland per unit area under the condition of no human input is $1 / 7$ of the actual food production. The ecosystem service values of one standard equivalent factor in 1990, 1995, 2000, 2005, 2010, and 2015 were $34.16,43.77,37.53$, 91.65, 198.41, and $189.18 \$ / \mathrm{hm}^{2}$, respectively. The ecosystem service value of one standard equivalent factor were calculated as follows:

$$
E_{a}=\frac{1}{7 \sum_{i=1}^{n} \frac{\mathrm{m}_{i} p_{i} q_{i}}{\mathrm{M}}} \times M C I
$$

...where $E_{a}$ is the economic value of ecosystem service value of one standard equivalent factor, $i$ is the type of crop, $\mathrm{m}_{i}$ is the national average price of the $i^{\text {th }}$ crop, $p_{i}$ is the yield per unit area of crop $i, q_{i}$ is the planting area of grain crop $i$, and $M C I$ is farmland multiple cropping index.
Combination with Table 1, ecosystem service values of one standard equivalent factor and regional regulation coefficient (ratio of grain yield per unit area of farmland in study area to that of farmland in China), the value per unit area of ecosystem service in the study area can be calculated (Table 4).

In this study, the dynamic value per unit area of ecosystem service of the study area was adjusted based on the biomass and precipitation regulation coefficient of each year in the study area. The total value of the ecological services of different land use categories in each period was calculated based on the land use data obtained from $1 \mathrm{~km}^{2}$, using the following formula:

$$
\mathrm{ESV}_{i j}=\left(\sum_{i, j=1}^{n} A_{i j} \times V C_{i j} \times P_{i j} \times R_{i j}\right)
$$

...where $\mathrm{ESV}_{i j}$ is the ESV of land use category $j$ in year $i, A_{i}$ is the area of land use category $j$ in year $i, V C_{i j}$ is the ecosystem service value per unit area $\left(\$ / \mathrm{hm}^{2}\right)$ of land use category $j$ in year $i, P_{i j}$ is the spatiotemporal regulating coefficient of NPP, and $R_{i j}$ is the regulating coefficient of precipitation.

Table 4. Value per unit area of ecosystem service of the study area in 2015 (unit: $\$ / \mathrm{hm}^{2}$ a).

\begin{tabular}{|c|c|c|c|c|c|c|}
\hline Type & Forest & Grassland & Cropland & Wetland & Water & Desert \\
\hline Food production & 5.88 & 7.67 & 17.83 & 6.42 & 9.45 & 0.36 \\
\hline Raw material & 53.13 & 6.42 & 6.95 & 4.28 & 6.24 & 0.71 \\
\hline Gas regulation & 77.02 & 26.74 & 12.84 & 42.97 & 9.09 & 1.07 \\
\hline Climate regulation & 72.56 & 27.81 & 17.29 & 241.57 & 36.73 & 2.32 \\
\hline Water purification and provision & 72.92 & 27.10 & 13.73 & 239.61 & 334.64 & 1.25 \\
\hline Waste purification & 30.66 & 23.53 & 24.78 & 256.73 & 264.75 & 4.64 \\
\hline Soil protection & 71.67 & 39.94 & 26.21 & 35.48 & 7.31 & 3.03 \\
\hline Biodiversity protection & 80.41 & 33.34 & 18.18 & 65.79 & 61.15 & 7.13 \\
\hline Recreation and culture & 37.08 & 15.51 & 3.03 & 83.62 & 79.16 & 4.28 \\
\hline Total & 501.33 & 208.06 & 140.84 & 976.46 & 808.52 & 24.78 \\
\hline
\end{tabular}


Table 5. Transfer rates and dynamic degrees of land use categories on the Loess Plateau (unit: \%).

\begin{tabular}{|c|c|c|c|c|c|c|c|c|c|c|}
\hline Year & $\begin{array}{c}\text { Paddy } \\
\text { fields }\end{array}$ & $\begin{array}{c}\text { Upland } \\
\text { areas }\end{array}$ & $\begin{array}{c}\text { Broad- } \\
\text { leaved }\end{array}$ & $\begin{array}{c}\text { Shrub } \\
\text { land }\end{array}$ & $\begin{array}{c}\text { Shrub-Grass- } \\
\text { land }\end{array}$ & $\begin{array}{c}\text { Water } \\
\text { area }\end{array}$ & Wetland & $\begin{array}{c}\text { Bare } \\
\text { land }\end{array}$ & Desert & $\begin{array}{c}\text { Dynamic } \\
\text { degree }\end{array}$ \\
\hline $1990-2000$ & -.144 & 0.006 & -0.029 & 0.34 & 0.229 & 0.12 & 2.455 & 0.68 & -1.949 & 5.952 \\
\hline $2000-2015$ & -.291 & -0.238 & 0.022 & 1.027 & -0.072 & 0.039 & 0.048 & 8.323 & -0.413 & 10.475 \\
\hline $1990-2015$ & -0.23 & -0.141 & 0.002 & 0.774 & 0.047 & 0.072 & 1.018 & 5.605 & -0.979 & 8.867 \\
\hline
\end{tabular}

\section{Results and Discussion}

\section{Land Use Transfer Rate and Dynamic Degree}

The transfer rate of land use categories can measure the speed of land use category transfer, and the dynamic degree can reflect the intensity of such a transfer. As shown in Table 5, the dynamic degree of land use categories from 1990 to 2015 was $8.867 \%$ in the study area. Apart from the transfer rate of paddy fields, the rates for dry land and desert decreased, while those of the other six categories (including broad-leaved forest, shrubbery, and shrub-grassland) increased. The rates for bare land were highest and reached 5.605\%, most likely as a result of accelerated urbanization. The transfer rates of wetlands, deserts, and shrub areas were 1.018, -0.979 , and $0.774 \%$, respectively. The dynamic degree of land use was $5.952 \%$ from 1990 to 2000, while the comprehensive dynamic degree was higher, reaching $10.475 \%$ from 2000 to 2015 . Among them, the reduction rates of paddy and desert areas and the increase rates of shrub and bare land areas were accelerating; for broad-leaved forest, rates decreased and then increased, while for upland areas rates first increased and then decreased. These changes can be explained by the various investments into the ecological construction of the Loss Plateau that have been made by the Chinese government since 1999 and include the comprehensive management of small river basins, the conversion of cultivated land to forest (grass), the construction of silt dams, and the improvement of slope farmland [32], resulting in a considerable improvement of the ecological environment.

\section{Transfer of Land Use Categories}

Changes of land use categories directly lead to changes in ecosystem service values. This paper first studied the transfer characteristics of land use categories in the study area from 1990 to 2000 and from 2000 to 2015. According to the transition matrix of the land use categories from 1990 to 2000 (Table 6), the stability rate of shrub-grassland was as high as $52.25 \%$, followed by the rates for upland and paddy areas with 48.87 and $29.67 \%$, respectively. The preservation rates of wetland and bare land were relatively low, at 9.8 and $20.18 \%$, respectively. Shrub areas were mainly converted into shrub-grassland and upland areas, with transfer areas of 1,757 and $1,143 \mathrm{~km}^{2}$, respectively, and 26.65 and $17.33 \mathrm{~km}^{2}$, respectively.

Paddy fields were mainly transferred into deserts, with a transfer area of $52 \mathrm{~km}^{2}$, accounting for $24.88 \%$ of the total area, while broad-leaved forest was mainly transformed into shrubland, with a transfer area of $1,114 \mathrm{~km}^{2}$ and a transfer ratio of $26.80 \%$. Remarkably, large areas $\left(11,608 \mathrm{~km}^{2}, 41.2 \%\right.$ of the total area) of

Table 6. Transition matrix of land use categories on the Loess Plateau from 1990 to 2000 (unit: $\mathrm{km}^{2}$ ).

\begin{tabular}{|c|c|c|c|c|c|c|c|c|c|c|}
\hline 2000 & $\begin{array}{c}\text { Paddy } \\
\text { fields }\end{array}$ & $\begin{array}{c}\text { Upland } \\
\text { areas }\end{array}$ & $\begin{array}{c}\text { Broad- } \\
\text { leaved forest } \\
\text { Forest }\end{array}$ & Shrubland & $\begin{array}{c}\text { Shrub-grass- } \\
\text { land }\end{array}$ & $\begin{array}{c}\text { Water } \\
\text { area }\end{array}$ & Wetland & $\begin{array}{c}\text { Bare } \\
\text { land }\end{array}$ & Desert & Total \\
\hline Paddy fields & 62 & 36 & 4 & 0 & 32 & 19 & 1 & 3 & 52 & 209 \\
\hline Upland areas & 43 & 13,769 & 615 & 1,329 & 11,608 & 134 & 82 & 183 & 411 & 28,174 \\
\hline $\begin{array}{c}\text { Broad-leaved } \\
\text { forest }\end{array}$ & 2 & 590 & 1,766 & 591 & 1,114 & 6 & 3 & 8 & 77 & 4,157 \\
\hline Shrub & 3 & 1143 & 579 & 3,001 & 1,757 & 14 & 10 & 24 & 63 & 6,594 \\
\hline Shrub-grassland & 29 & 11,736 & 1,054 & 1,779 & 17,775 & 151 & 111 & 137 & 1,245 & 34,017 \\
\hline Water area & 7 & 146 & 8 & 12 & 130 & 123 & 37 & 10 & 24 & 497 \\
\hline Wetland & 4 & 61 & 2 & 9 & 92 & 21 & 22 & 8 & 5 & 224 \\
\hline Bare land & 4 & 174 & 10 & 12 & 122 & 10 & 3 & 89 & 17 & 441 \\
\hline Desert & 52 & 539 & 107 & 85 & 2,170 & 25 & 10 & 9 & 2,658 & 5,655 \\
\hline Total & 206 & 28,194 & 4,145 & 6,818 & 34,800 & 503 & 279 & 471 & 4552 & 79,968 \\
\hline
\end{tabular}


Table 7. Transition matrix of land use categories on the Loess Plateau from 2000 to 2015 (unit: km²).

\begin{tabular}{|c|c|c|c|c|c|c|c|c|c|c|}
\hline 2000 & $\begin{array}{c}\text { Paddy } \\
\text { fields }\end{array}$ & $\begin{array}{c}\text { Upland } \\
\text { areas }\end{array}$ & $\begin{array}{c}\text { Broadleaved- } \\
\text { forest }\end{array}$ & Shrubland & $\begin{array}{c}\text { Shrub-grass- } \\
\text { land }\end{array}$ & $\begin{array}{c}\text { Water } \\
\text { areas }\end{array}$ & Wetland & $\begin{array}{c}\text { Bare } \\
\text { land }\end{array}$ & Desert & Total \\
\hline Paddy fields & 192 & 4 & 0 & 1 & 0 & 5 & 1 & 3 & 0 & 206 \\
\hline Upland areas & 0 & 26,874 & 11 & 631 & 503 & 11 & 5 & 159 & 4,230 & 28,195 \\
\hline $\begin{array}{c}\text { Broad-leaved } \\
\text { forest }\end{array}$ & 0 & 15 & 4,089 & 10 & 7 & 0 & 1 & 22 & 1 & 4,145 \\
\hline Shrubland & 0 & 9 & 4 & 6,765 & 11 & 0 & 0 & 21 & 1 & 6,818 \\
\hline Shrub-grassland & 0 & 160 & 51 & 458 & 33,778 & 10 & 4 & 308 & 8 & 34,803 \\
\hline Water areas & 3 & 5 & 1 & 1 & 3 & 455 & 32 & 3 & 34 & 503 \\
\hline Wetland & 1 & 16 & 0 & 0 & 2 & 19 & 236 & 5 & 0 & 279 \\
\hline Bare land & 0 & 4 & 1 & 0 & 4 & 3 & 1 & 458 & 0 & 471 \\
\hline Desert & 1 & 101 & 2 & 3 & 119 & 3 & 1 & 96 & 0 & 4,556 \\
\hline Total & 197 & 27,188 & 4,159 & 7,869 & 34,427 & 506 & 281 & 1,075 & 4,274 & 79,976 \\
\hline
\end{tabular}

upland fields were transferred into shrubland, while the area of shrubland transferred into upland was $11,736 \mathrm{~km}^{2}$, accounting for $34.5 \%$ of the total area. Most likely, inadequate cultivation methods and the unreasonable use of resources have led to this trend. In addition, after preliminary farmland improvement and the protection of the ecological environment, the implementation of the "returning farmland to forest and grassland" program in some areas has gradually facilitated this development, resulting in the large-scale ecological restoration of degraded areas.

The area of shrubland changed most dramatically from 2000 to 2015 (Table 7), with an increase by $1,007 \mathrm{~km}^{2}$, while the upland area decreased by $1,051 \mathrm{~km}^{2}$. The area of bare land increased by $604 \mathrm{~km}^{2}$, while the areas of broad-leaved forest, wetland, and waterbodies increased slightly, indicating that the land use pattern changed from the production of local goods to the provision of overall ecosystem services. The driving force behind this development is the focus on ecological restoration since 1999, with programs such as "returning farmland to forest and grassland," grazing prohibition, forest cultivation, and various environmental protection measures. In contrast, the excessive use of land resources and, consequently, large-scale deforestation have been curbed, and agricultural production and resource use are now mainly based on scientific evidence. Also, the rapid development of China's social economy, the acceleration of urbanization, the large-scale transfer of rural laborers to secondary and tertiary industries, and the changes in China's energy structure - especially the promotion of clean energy in rural areas - have reduced the daily demand for firewood, which has led to significant ecological changes [33-34].

From 1990 to 2015, dramatic changes occurred in terms of land use, with poor ecosystem stability. The use of environmental resources was based on scientific evidence, and as a result, the quality of the ecological environment improved rapidly. The area of bare land, dominated by construction, increased rapidly, while the cultivated land area first increased and then decreased. Grassland areas were slightly reduced, while the areas of wetlands and rivers were stable.

\section{Spatial and Temporal Patterns of ESV and Changes}

\section{Time Series Changes of ESV}

From 1990 to 2015, the total value of all ecosystem services on the Loess Plateau increased from $\$ 175.4$ million to $\$ 4.93$ billion, which is an increase of more than 30 times (Table 8). From 1990 to 2000, the total value of ecosystem services maintained an average annual growth rate of $11 \%$. During this period, the value presented a "concave" change trend, that is, from $\$ 175.4$ million in 1990 to $\$ 95.00$ million in 1995 and to $\$ 387.61$ million in 2000 . From then on, the value of ecosystem services increased rapidly, with an average annual growth rate of $72 \%$ from 2000 to 2015 , which peaked from 2000 to 2010 and showed a slight downward trend in 2015. The change of the ecosystem service value on the Loess Plateau may be closely related to the implementation of the world's largest project of returning cultivated land to forest and grassland in China [35], with the aim to improve the quality of the regional ecological and environment.

The ecological service value of land categories was always highest in grassland, growing from $\$ 91.47$ million to $\$ 2.13$ billion, with an average annual growth of $\$ 78.37$ million from 1990 to 2015 . The value of upland ecological services increased from \$13.15 million to $\$ 1.49$ billion, an increase of nearly $\$ 1.47$ billion in 25 years, while the value of forest ecosystem services increased from $\$ 64.47$ million to $\$ 1.17$ billion. Grassland, dry land, woodland, and water areas accounted for more than $97 \%$ of the value of ecological services in 2015. During the periods 1990-2000 and 2000-2015, 
Table 8. ESV of different land use categories in the Loess Plateau of northern Shaanxi province.

\begin{tabular}{|c|c|c|c|c|c|c|c|c|}
\hline \multirow{2}{*}{$\begin{array}{l}\text { Land use } \\
\text { categories }\end{array}$} & \multicolumn{6}{|c|}{ ESV of $1990-2015\left(10^{5} \$ / \mathrm{hm}^{2 \cdot} \cdot \mathrm{a}^{-1}\right)$} & \multirow{2}{*}{$\begin{array}{c}\text { Annual change rate } \\
\text { of ESV }\end{array}$} & \multirow{2}{*}{$\begin{array}{c}\text { Annual change rate } \\
\text { of ESV }\end{array}$} \\
\hline & 1990 & 1995 & 2000 & 2005 & 2010 & 2015 & & \\
\hline Paddy fields & 0.65 & 0.59 & 0.40 & 1.78 & 9.61 & 157.26 & -0.03 & 24.51 \\
\hline Upland areas & 131.54 & 57.06 & 92.55 & 458.47 & $2,742.81$ & $14,863.65$ & -0.03 & 9.98 \\
\hline $\begin{array}{l}\text { Broad-leaved } \\
\text { forest }\end{array}$ & 311.71 & 212.87 & 335.80 & $1,340.81$ & $5,419.09$ & $4,359.00$ & 0.01 & 0.75 \\
\hline Shrubland & 333.05 & 218.60 & 448.18 & $2,011.27$ & $8,433.08$ & 7299.52 & 0.04 & 0.87 \\
\hline Shrub-grassland & 914.66 & 438.42 & $2,895.15$ & $13,197.12$ & $52,832.87$ & $21,290.50$ & 0.20 & 0.40 \\
\hline Waters areas & 47.97 & 18.29 & 28.44 & 137.23 & 861.77 & 263.78 & -0.04 & 0.52 \\
\hline Wetland & 11.73 & 3.46 & 14.80 & 59.68 & 322.41 & 124.32 & 0.02 & 0.46 \\
\hline Bare land & 0.10 & 0.04 & 0.13 & 0.02 & 3.57 & 8.63 & 0.03 & 4.09 \\
\hline Desert & 2.44 & 0.60 & 20.66 & 65.53 & 369.49 & 966.69 & 0.68 & 2.86 \\
\hline Total & $1,753.85$ & 949.93 & $3,876.11$ & $17,271.91$ & $70,994.70$ & $49,333.35$ & 0.11 & 0.72 \\
\hline
\end{tabular}

the average annual growth rate of shrub-grassland was 20 and $40 \%$, respectively. In 2015, the value of grassland ecological services accounted for $43 \%$ of the total value, indicating that ecological services value in the research area has rapidly been increasing since the $21^{\text {st }}$ century. From 1990 to 2000 , the value of ecological services in paddy, upland, and water areas declined year by year, with an average annual decline rate of 3,3 , and $4 \%$, respectively. In contrast, the values of ecological services for paddy and upland areas increased rapidly from 2000 to 2015, indicating that on the Loess Plateau region, the ecological services value for agricultural land has greatly been improved through the Grain for Green Program and the Three North Shelterbelt Development Program optimizing. In addition, The Chinese government strongly advocates farmers adjusting agricultural planting structure and vigorously developing green agriculture, which is one of the main human factors that lead to the change of ecological services value. However, the value of ecological services decreased by 2.4 million per year from 2010 to 2015 , indicating that the ecological environment in the study area is still fragile due to its complexity and vulnerability and because of the diverse human activities. This means that more attention should be paid to the maintenance and protection of the ecological environment, especially when developing and establishing social and economic construction projects. Against this background, grazing and deforestation guidelines must be based on scientific principles, with the focus on avoiding further land degradation.

\section{Spatial Patterns and Changes in ESV}

The ecosystem service value distribution maps of the six periods from 1990 to 2015 were obtained based on the GIS raster statistical method (Fig. 2). On the Loess
Plateau of northern Shaanxi Province, the values were high in the southeast and low in the northwest. The high-value regions were mainly located in the southern mountainous areas, including the counties Fuxian, Huangling, and Huanglong, while the low-value regions were distributed in the western and northern parts of the study area. Regions with medium values were mainly distributed in the southern region of the Luohe River Basin. The environmental quality of the study area increased significantly, albeit with a high spatial heterogeneity; the southern regions had a significantly higher quality than the northern regions, which are heavily impacted by the energy and chemical industries.

Changes in ESV were mainly concentrated in the southern mountains, and the high-value area of the ecological services value presented a "V"-type change, that is, "first decline and then rise," while the northern area did not change significantly from 1990 to 2000. This phenomenon is due to the two distinct states under the positive and negative impacts of human activities. The one reason is environmental degradation (soil erosion and water loss, vegetation coverage decreases, desertification) caused by unreasonable exploitation and inadequate resource use in this area. Another reason is that the implementation of largescale ecological environmental programs has gradually improved environmental quality. It is important to point out is that the distribution range of low-value areas expanded from the Luohe River Basin (southern section) to the east and west, which is related to urban construction, overexploitation of minerals and energy, and unreasonable resource use along the Luohe River. From 2000 to 2015, the range of high-value and medianvalue areas extended from southeast to northwest and from the northwestern marginal areas, with the most obvious changes from 2005 to 2010. High-value areas 


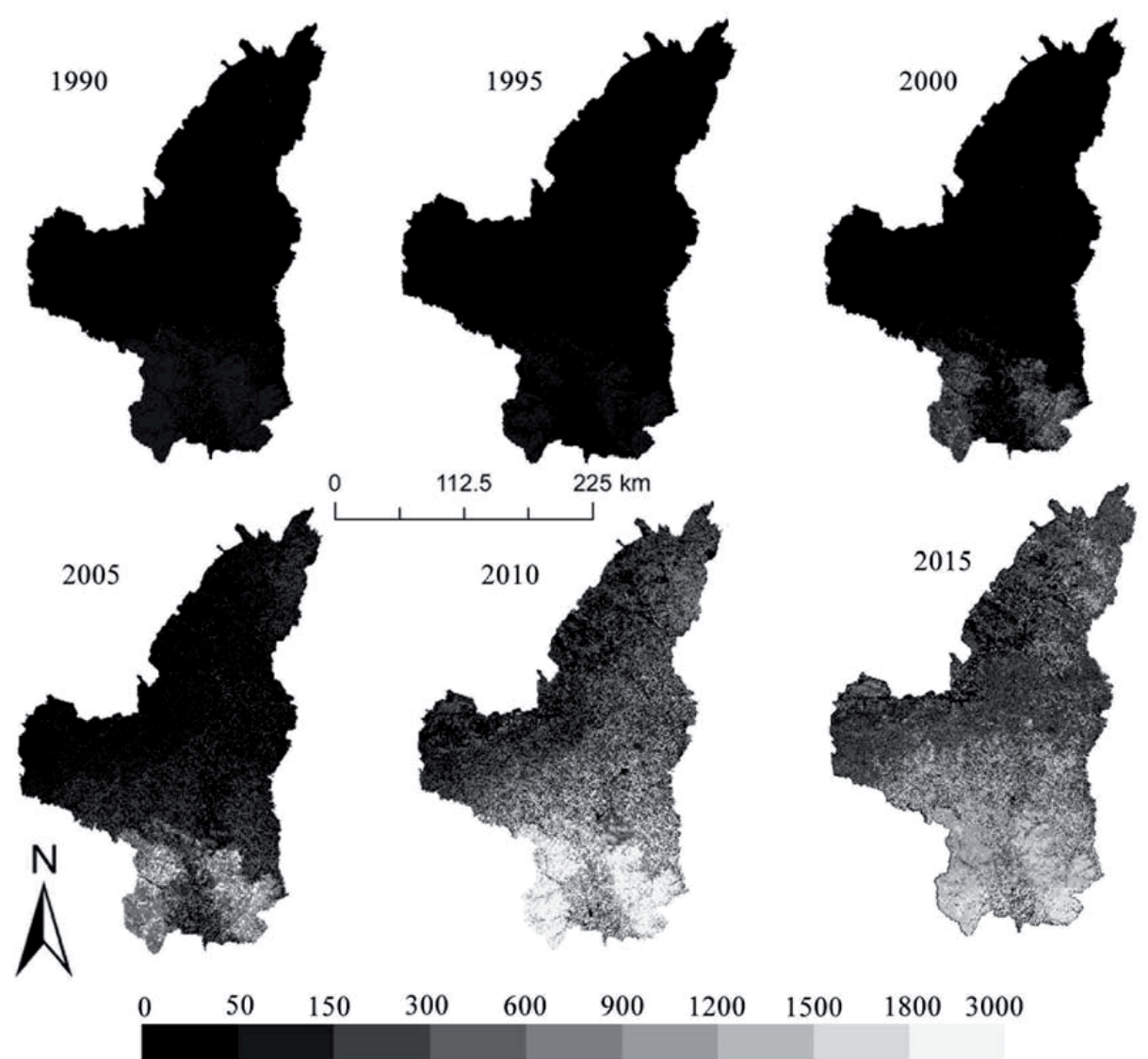

Fig. 2. Distribution of per unit ecosystem service values of the Loess Plateau in northern Shaanxi from 1990 to 2015 (unit: $\$ / \mathrm{hm}^{2}$ ).

extended to the northeastern part of the region, with large improvements; however, the ecological service values were slightly lower in the central and northern areas, mainly as a result of accelerated urbanization, industrialization, and overgrazing. Although the spatial and temporal pattern and changes of ESV in the study area were quantified by the equivalent factor method, this paper did not discuss the factors influencing the variation of ESV, especially the quantitative research on the impact of human activities and climate change. The following research will use pixel-based multiple regression analysis and second-order partial correlation analysis to quantify the impact of human activities and climate factor changes on ESV, respectively.

\section{Conclusions}

This paper analyzed the transfer rate, dynamic degree, and the transfer relation of land categories based on land use, NPP, and meteorological data from the Loess Plateau of northern Shaanxi Province in the period from 1990 to 2015. At the same time, the ESV of nine land use categories and their spatio-temporal variation characteristics were evaluated through a dynamic regulation of the "unit area ecological service value dynamic equivalent factor of the Chinese ecosystem." The results are as follows:
- The dynamic degree of land use categories in the study area was $8.87 \%$ from 1990 to 2015 . In particular, the dynamic degrees of the land use categories from 1990 to 2000 and from 2000 to 2015 were 5.95 and $10.48 \%$, respectively. The reduction rates of paddy fields and desert and the increase rates of shrubby forests and bare land increased, while the areas of broad-leaved forest increased and desert area decreased.

- From the perspective of land use change, the bare land area dominated by construction land increased rapidly, while forest land showed steady growth. The area with cultivated land first increased and then decreased, while the grassland area decreased slightly and the wetland and water areas tended to be stable. The ecosystem service value of the Loess Plateau region of northern Shaanxi significantly fluctuated from 1990 to 2015. In the period from 1990-1995, the growth was negative, while from 1995-2010, a positive and continuous growth was observed; from 2010-2015, the value slightly declined. The ecosystem service values presented an obvious spatial heterogeneity, with significantly higher values in the southern region from 1990 to 2015. From 1990 to 2000, the value of the southern mountainous area showed a "V-shaped" change trend, and the low-value area of the southern section of the Luohe River Basin expanded from the river channel to 
the east and west. In contrast, from 2000-2015, the highvalue and medium-value areas gradually moved from the southeast to the northwest, and the change within the period from 2005-2010 was particularly obvious.

According to the result of this paper, the authors have some suggestions for future development that can be put forward. This study found that ESV in the central Loess Plateau has undergone significant fluctuations in the past two decades. However, this study did not conduct quantitative research on the natural and human factors that cause ESV fluctuations. Therefore, research on the natural and human factors of ESV changes will be the key issues in the following research.

\section{Acknowledgements}

The authors would like to pay special thanks to the National Science and Technology Infrastructure of China, Data Sharing Infrastructure of Earth System Science - Data Center of Lower Yellow River Regions (http://henu.geodata.cn). This research was supported by the National Natural Science Foundation of China (Nos. 41671536 and 41501588) and the International Cooperation Laboratory of Geospatial Technology for Henan province (No. 152102410024).

\section{Conflict of Interest}

The authors declare no conflict of interest.

\section{References}

1. TANSLEY A.G. The use and abuse of vegetational concepts and terms. Ecology. 16, 284, 1935.

2. DAILY G.C. Nature's services: societal dependence on natural ecosystems. Pacific Conservation Biology. 6 (2), 220, 1997.

3. YAN E.P., LIN H., WANG G.X., XIA C. Analysis of evolution and driving force of ecosystem service values in the Three gorges reservoir region during 1990-2011. Acta Ecologica Sinica. 34 (20), 5962, 2014.

4. SCHMALZ B., KRUSE M., KIESEL J., MULLER F., FOHRER N. Water-related ecosystem services in Western Siberian lowland basins analysing and mapping spatial and seasonal effects on regulating services based on ecohydrological modelling results. Ecological Indicators. 71, 55, 2016.

5. LUAN J.K., LIU D.F., HUANG Q., FENG J.L., LIN M., LI G.B. Analysis of the spatial-temporal change and impact factors of the vegetation index in Yulin, Shaanxi Province, in the last 17 years. Acta Ecologica Sinica. 38 (8), 2780, 2018.

6. LIU G.B., SHANGGUAN Z.P., YAO W.Y., YANG Q.K., ZHAO M.J., DANG X.H., GUO M.H., WANG G.L., WANG B. Ecological effects of soil conservation in Loess Plateau. Bulletin of Chinese Academy of Sciences. 32 (1), 11, 2017.

7. ZHANG H.Y., FANG N.F., SHI Z.H. Spatio-temporal patterns for the NDVI and its responses to climatic factors in the Loess Plateau, China. Acta Ecologica Sinica. 36 (13), 3960, 2016.

8. ZHAO A.Z., ZHANG A.B., LIU H.X., LIU Y.X., WANG H.F., WANG D.L. Spatiotemporal variation of vegetation coverage before and after implementation of grain for green project in the Loess Plateau. Journal of Natural Resources. 32 (3), 449, 2017.

9. LANGNER A., IRAUSCHEK F., PEREZ S., LEXER M. Value-based ecosystem service trade-offs in multiobjective management in European mountain forests. Ecosystem Services. 26, 245, 2017.

10. CAO Q.W., WEI X.M., WU J.S. A review on the tradeoffs and synergies among ecosystem services. Chinese Journal of Ecology. 35 (11), 3102, 2016.

11. LI Y., LI S.C., GAO Y., WANG Y. Ecosystem services and hierarchic human well-being: Concepts and service classification framework. Acta Geographica Sinica. 68 (8), 1038, 2013.

12. OUYANG Z.Y., ZHU C.Q., YANG G.B., XIAO Y. Gross ecosystem product: Concept, accounting framework and case study. Acta Ecologica Sinica. 33 (21), 6747, 2013.

13. LI Y., XIE Z., QIN Y., ZHENG Z. Estimating Relations of Vegetation, Climate Change, and Human Activity: A Case Study in the $400 \mathrm{~mm}$ Annual Precipitation Fluctuation Zone, China. Remote Sensing. 11 (10), 1159, 2019.

14. COSTANZA R., D'ARGE R., GROOT R.D., FARBER S., GRASSO M., HANNON B., LIMBURG K., NAEEM S., O'NEILL R., PARUELO J., RASKIN R., SUTTON P., BELT $M$. The value of the world's ecosystem services and natural capital. Nature. 387, 253, 1997.

15. MA F.J., LIU J.T. A review of ecosystem services and research perspectives. Acta Ecologica Sinica. 33 (19), 5963, 2013.

16. XIE G.D., ZHEN L., LU C.X. Expert acknowledge based evaluation method of ecosystem services in China. Journal of Natural Resources. 23 (5), 911, 2008.

17. TANG X., CHEN B., LU Q.B., HAN F. The ecological location correction of ecosystem service value: a case study of Beijing City. Acta Ecologica Sinica. 21 (13), 3526, 2010.

18. ZHANG X.N., SONG H.L., LI Z.J. Study on spatial distribution of regional ecosystem service value based on Geo-statistics. Research of Soil and Water Conservation. 19 (6), 168, 2012.

19. LI Y.Q., DENG O., ZHANG D.Y., HAN D., FENG Z. Land use and ecosystem service value scenarios simulation in Danjiangkou reservoir area. Transactions of the CSAE. 27 (5), 329, 2011.

20. BAI Y., ZHENG H., ZHUANG C.W., OUYANG Z. Ecosystem services valuation and its regulation in Baiyangdian baisn: Based on InVEST model. Acta Ecologica Sinica. 33 (3), 711, 2013.

21. MANSOOR D.K., LEHA M.D., MATLOCKA E.C., NALLEY L.L. Quantifying and mapping multiple ecosystem services change in West Africa. Agriculture, Ecosystems and Environment. 165 (1751), 6, 2013.

22. SU C.H., FU B.J. Evolution of ecosystem services in the Chinese loess plateau under climatic and land use changes. global and planetary change. 101 (1), 119, 2013.

23. CAO Y.G., BAI Z.K., JING M., ZHANG Z.M., LU Y.Q., SONG X.J., DU Z. Research on regional ecological service value based on land use changes. Research of Soil and Water Conservation. 20 (6), 256, 2013.

24. DU X., HUANG Z. Ecological and environmental effects of land use change in rapid urbanization: The case of Hangzhou, China. Ecological Indicators. 81, 243, 2017. 
25. LIU H., WU J., CHEN X.L. Study on spatial-temporal change and trade-off/synergy relationships of ecosystem services in the Danjiangkou water source area. Acta Ecologica Sinica. 38 (13), 4609, 2018.

26. LI J., REN Z.Y. Spatio-temporal change of water conservation value of Loess Plateau ecosystem in northern Shaanxi province. Chinese Journal of Ecology. 27 (2), 240, 2008.

27. LIU X., ZHAO Y.X., WU A.B., QIN Y.J. Land use changes and its anthropogenic driving factors in hilly region, Hebei Province. Research of Agricultural Modernization. 36 (1), 126, 2015.

28. LIU J.Y., KUANG W.H., ZHANG Z.X., XU X.L., QIN Y.W., NING J., ZHOU W. C., ZHANG S.W., LI R.D., YAN C.Z., WU S.X., SHI Z.X., JANG N, YU S.D., PAN X.Z., CHI W.F. Spatio-Temporal characteristics, patterns and causes of land- use changes in China since the late 1980s. Journal of Geographical Sciences. 69 (1), 3, 2014.

29. XIE G.D., ZHANG C.X., ZHANG L.M., CHEN W.H., LI S.M. Improvement of the evaluation method for ecosystem service value based on per unit area. Journal of Natural Resources. 3 (8), 1243, 2015.

30. LI S.M. Studies on the flow processes of typical ecosystem services based on observation network. Beijing: Institute of Geographic Sciences and Natural Resources Research. CAS, 2010.

31. PEI S. Flow processes of typical ecosystem services and their value based on data from field stations. Beijing: Institute of Geographic Sciences and Natural Resources Research. 2013.

32. SONG M.M., ZHANG Q.F., WU Q.F. Landscape pattern changes and evaluation of ecological service values in a small watershed of the Loess Gully region. Acta Ecologica Sinica. 38 (8), 2649, 2018.

33. LIU X.Y., YANG S.T., LI X.Y. The current vegetation restoration effect and its influence mechanism on the sediment and runoff yield in severe erosion area of Yellow River Basin. Science in China Series E: Technological Sciences. 45 (10), 1052, 2015.

34. YAO W., RAN D., CHEN J. Recent changes in runoff and sediment regimes and future projections in the Yellow River basin. Advances in Water Science. 24 (5), 607, 2013.

35. LI Y., XIE Z., QIN Y., SUN Y. Temporal-Spatial Variation Characteristics of Soil Erosion in the Pisha Sandstone Area, Loess Plateau, China. Polish Journal of Environmental Studies. 28 (4), 2205, 2019. 
